and technology covers ground that is common to the arts and science; and the problems of liberalizing science courses and of interesting arts students in science may be solved by courses in these subjects.

Experience in the field of extramural studies shows that there is considerable interest in such topics and in the philosophy of science. A number of experimental courses in the history of science have been given, and in these the 'case-book' method developed by J. B. Conant at Harvard University ${ }^{2}$ has been used and considerably extended. In the most successful courses various important experiments in the history of science, such as the analysis of light, the discovery of oxygen and the discovery of the electron, have been described and demonstrated, and their scientific and technological consequences discussed. One surprising feature of these lectures has been the large attendance of senior sixth-form grammar school pupils.

It has already been suggested that courses on the impact of science on society might very well be suitable for the Workers' Educational Association. Such courses have been given at the request of local Association branches; but generally the response has been very poor. Very much more could and should be done in this field; a technological society is obviously extremely unstable if its members are ignorant of and uninterested in technological developments and the problems which these pose.

There are certain parts of courses in history and economics in which contributions from scientific specialists are essential. Only a scientist can adequately assess the influence of scientific discoveries on the climate of scientific opinion and on technological development. Such experience as we have had indicates that, provided problems of continuity can be solved, joint extramural courses by, for example, a historian and a scientist are very successful.

Certain general conclusions may be drawn from what has been said above. For example, it seems desirable that extramural staffs (at any rate in science) should be primarily advisers and organizers, although they should obviously keep in touch with their subjects by research and by internal and external teaching. This means, of course, that the bulk of extramural science teaching will be done by internal members of university staffs. The university, however, has obligations to the community in which it is situated, and to the tax-payer who nowadays largely finances it. The discharge of such obligations may very well involve, among other things, the explanation of the nature, purpose and results of the research work which is being done by universities.

Although extramural departments should be prepared to co-operate with all who seek their help, their main concern should always be with the provision of courses, delivered at a university level, for those who are capable of benefiting from them. In practice, these will probably be ex-grammar school people whose spare time is often limited. Hence, much of this provision must be in the form of short intensive one-day, week-end or residential courses and series of, say, not more than six evening lectures.

The activities of extramural departments should be widely known and this means that extensive advertising of courses is necessary. This has the additional advantage that students recruited to an advertised course form a reasonably homogeneous group.
The extramural department should, at this time, be encouraged to investigate every possible field of activity open to it. Experimental work and courses of all kinds should be tried; and this means that its activities should not be artificially restricted by financial straitjackets or by out-worn regulations. For example, sixth-form grammar school students are not officially admitted to extramural lectures and classes. Yet they are adult; they are capable of absorbing information at the appropriate level ; they are prepared to turn up voluntarily in large numbers for lectures on the history of science and on modern scientific and technological developments; and they are the extramural students of to-morrow. If they are encouraged to-day to look to the university, through its extramural department, for their further cultural education, the problem of recruitment to classes in the future may very well solve itself.

There can be no doubt that in order to achieve all this it will be necessary for extramural departments to be directed solely by the university council and senate working through appropriate committees. This would give the departments the necessary status and flexibility of approach ; and the obvious corollary to this is that the money required to finance their activities should be provided by the University Grants Committee as for other university departments.

1 Peers, Robert, "Science in the Extramural Work of the Universities" (Universities Council for Adult Educaticn). See Nature, 174, (Universities
166 (1954).

"Conant, J. B., "Harvard Case Histories in Experimental Science" (Harvard Ưniversity Press, 1950).

\section{RADIATION HAZARDS IN INDUSTRY}

$T$

HE third conference of the British Occupational Hygiene Society was held on November 1 in the lecture theatre of the London School of Hygiene and Tropical Medicine, the subject of the conference being a consideration of the radiation hazards in industry. The chair was taken by Prof. E. J. King (Postgraduate Medical School of London). The subject was originally introduced at the second conference of the Society held in April 1954 when Dr. W. G. Marley (Atomic Energy Research Establishment, Harwell) delivered a paper on the permissible levels: of exposure to ionizing radiations and radioactive materials. In this paper Dr. Marley discussed the basic 'tolerance' level or maximum permissible level. for $\mathrm{X}$-rays or gamma-rays, and then proceeded from. the basic 'tolerance' for X-rays and gamma-rays to calculate the permissible exposure to various types of radiation, allowing for their relative biological effectiveness. Similarly, the maximum permissible body-burden of radium is a valuable starting-point for the calculation of maximum permissible levels of different radioactive isotopes taken into the body. Dr. Marley described the method by which international agreement on maximum permissible levels has been reached. The experience of the atomic energy departments and of radiobiological specialists in the United States, Canada and the United Kingdom has been compared in a series of tripartite conferences commencing in 1949. Since then, data have been considered by the International Commission on Radiological Protection during the meetings of the International Congress of Radiology in 1950 and 
1953. The third conference of the British Occupational Hygiene Society therefore started with a knowledge of the maximum permissible levels and with the assurance that they are internationally agreed levels.

Dr. A. S. McLean (principal medical officer of the Industrial Group, United Kingdom Atomic Energy Authority) opened the third conference of the Society with a paper on the health of workers exposed to ionizing radiation. He referred to the history of man's use of atomic energy since the turn of the century up to the present time, when he has learned to exploit it on a grand scale. Dr. McLean was less concerned with the effects of massive doses of radiation than with the pattern of injury which may be the outcome of long-continued exposure just above the critical level for these effects. The consequences of chronic over-exposure have been seen in several groups of human beings, including painters of luminous dials, miners of radioactive ores, and pioneer workers in the scientific and medical fields; in addition, there has been a vast amount of experimental work with animals. From these observations it is known that the sensitivity of any organ of the body to the effects of irradiation is generally a function of the rate of cellular activity in that organ, so that the bloodforming and reproductive tissues, for example, are more easily damaged than the nerve tissue of the brain. Nevertheless, a tissue of relatively low sensitivity may be damaged exclusively when it is the site of selective localization of a radioactive substance which has entered the body. Thus, radiation protection contains two distinct problems which are concerned with the irradiation of whole or part of the body from the outside and with the irradiation of selected organs of the body following uptake of a radioactive substance by breathing or by swallowing. Dr. McLean discussed both these problems and listed the main body organs involved. Of particular interest to the medical officer is the detection of radioactivity in the excreta ; but since in some cases this involves the determination of micromicro-gram quantities of radioisotopes, the radiochemistry involved is not easy. Dr. McLean concluded with a review of the comprehensive medical facilities which are used in the selection of workers and in the maintenance of health in the workers employed in the atomic energy industry.

The second paper, dealing with radiation safety in the Industrial Group of the United Kingdom Atomic Energy Authority, was by Mr. D, R. R. Fair (head of the Health Physics Department, Windscale Works, Sellafield, Cumberland). He reminded the audience that, in thinking of radiation safety in industry, they must not think of scientists working in laboratories but of factory managers employing process workers and skilled craftsmen working in factories. Hé discussed external irradiation and the design office's contribution to the safety of the worker in the provision of radiation shields and the layout of plant and equipment to make use of distance for safety.

The contribution by works management to safety is called for when plant has to be maintained or modified. A decision has to be made whether to postpone operations in order to allow short-lived fission products to suffer radioactive decay or whether the radiation field may be reduced by decontamination of the plant. Before work commences, management has to decide whether local radiation shielding must be built, the workers have to be briefed on the method and sequence of work they are to carry out, and the time the worker is in the radiation field has to be carefully controlled. Mr. Fair then turned to the harder task of the atomic energy industry, the protection of the worker from the inhalation or ingestion of radioactive materials. The design offices have provided all-welded plant using a specially corrosion-resistant stainless steel, liquid transfer mechanisms by hypodermic needle, and adequate ventilation of working space with controlled direction of airflow and proper facilities for the workers to maintain the highest levels of personal hygiene. The management exercises safely control during maintenance work by reducing air contamination to a minimum, controlling both the volume of air which is contaminated and its disposal, and by providing the worker with clean air and full head and body cover while he is on the job. Mr. Fair discussed in some detail the methods by which management achieves these aims. He concluded by reviewing the position and responsibilities of the health physicist in an atomic energy works.

Mr. W. Binks (Radiological Protection Service of the Ministry of Health and the Medical Research Council) presented the third paper, and dealt with protection against $\mathrm{X}$-rays and gamma-rays in the industrial field. He was particularly concerned with radiation hazards in ordinary industries. Experimental data were given on the direct radiation outputs from $X$-ray tubes and from radioactive isotopes, on the degree of scattering produced under different conditions and on the absorption of both direct and scattered radiation in materials such as lead, brick, concrete and soil. Mr. Binks discussed in detail the solution of a number of problems encountered in designing an industrial radiological establishment. Since the safety of personnel working with ionizing radiations depends as much upon adherence to particular techniques as upon the provision of structural shielding, Mr. Binks included details of the various monitoring techniques which may be adopted to assess the actual dose received by workers. Finally, he described the help which it is anticipated the Radiological Protection Service will give to industrial managements in designing radiological establishments and in carrying out radiation surveys and personnel monitoring tests.

The final paper at the conference was by $\mathrm{Mr}$. F. R. Farmer, assistant director, production, of the Industrial Group, United Kingdom Atomic Energy Authority, Risley, who dealt with the safety criterion in atomic energy. Mr. Farmer made a review of the hazard-level in industry as measured by the death-rate and compared this in the working population age-group with the death-rate due to natural causes and to violence. He quoted deathrates of 10-12 for normal industry, 30 due to violence (including 12 on the roads), 80 for the mines and 140 due to natural causes, all per 100,000. In a civilization with a rising standard of living, changes in the public attitude to such figures may be expected and $a$ demand will arise for preventive action to be taken.

Mr. Farmer posed the problem of the new industry and asked what should its objective be. While it may be argued that a zero risk is highly desirable, this, in the absolute sense, is not obtainable. It seems reasonable to set as a target for a new industry that it must be comparable with the best in other industries. Looking back over other industries, it is probable that safety has been influenced by the need of the industry to sell its products economically in a competitive market, and the cost factor in safety 
must not be lost sight of if the atomic energy industry is to make its mark in the national economy. Mr. Farmer concluded that the safety aim of the atomic energy industry must be for perfection within an economic framework that will encourage the development of the industry.

Each paper presented to the conference was followed by a period of full discussion in which many points of principle and some of detail were discussed. It was agreed that the safety-level established in the atomic energy field compares very favourably with much of established industry, but that a larger experience of radioactive work in industry will be needed before final conclusions can be drawn.

D. R. R. FAIR

\section{RESEARCH ASSOCIATION OF BRITISH RUBBER MANUFACTURERS}

\section{OPENING OF NEW LABORATORIES NEAR SHREWSBURY}

$\mathrm{O}^{\mathrm{s}}$ November 23 H.R.H. the Duke of Edinburgh officially opened the new laboratories and headquarters at Shawbury, near Shrewsbury, of the Research Association of British Rubber Manufacturers. Some three hundred persons were present, drawn from all sections of the rubber and allied industries, together with representatives of government departments and other organizations connected with the rubber industry, and after the opening they were able to visit the premises and inspect the displays showing various aspects of the Association's work. In his speech to the company the Duke referred to the obligations of industry towards cooperative research and its results, and put in a strong plea for yet more generous financial support by industry of the Association's work. He also stressed very much the problem of getting a research association's results applied in industry - "probably the most complicated and elusive problem confronting the industry to-day".

The ceremony formed a fitting and stimulating climax to the efforts that have been made during the past years to provide the Association with premises adequate for its growing needs. Founded in 1919, the Research Association of British Rubber and Tyre Manufacturers (as it was first called) began work in two rooms in University College, London, and then in 1922 premises were acquired in Lansdowne Road, Croydon. For many years these met the Association's needs ; but the very success of its work, and especially the demands made on it during the Second World War, led to an expansion that seriously overtaxed the available space. By 1948 it became clear that the only solution was to find entirely new premises, and bearing in mind that the 'centre of gravity' of the rubber industry lies in the Midlands rather than the London area, the Council of the Association decided, after exhaustive inquiries and searches, to acquire premises already existing at Shawbury. These were purchased in January 1952, and since then the task of adapting them has proceeded steadily. Now that task is complete and the premises have been officially opened, the industry possesses a research station of excellent design, attractive in external appearance and interior finish, and fully equipped for the important work that lies before it.

The new premises (Fig. 1) are near the village of Shawbury, $6 \frac{1}{2}$ miles north-east of Shrewsbury on the Market Drayton Road ( $A$ 53). Erected in 1938 by Shropshire County Council, they have a floor area of some $15,000 \mathrm{sq}$. ft. and stand on a level site of about $6 \frac{1}{2}$ acres. The whole building is on one floor, except for two flats over the front portion. Although built for a different purpose, the lay-out has proved surprisingly convenient for the laboratories, library, workshops and offices of the Research Association.

The laboratories proper are grouped into three categories: chemistry, physics and technology. The chemical laboratories are in two groups. In the first, the main laboratory is for analytical work, including the testing of raw materials, analysis of vulcanized rubbers, identification and estimation of synthetics, and so on, and has for this purpose many pieces of specialized apparatus. The equipment includes also a micro-balance, used in developing micro-chemical techniques applicable to rubbers and other polymers, a Spekker absorptiometer for colorimetric analyses, and an infra-red spectrometer which has been devoted particularly to the identification of organic accelerators and antioxidants in vulcanized rubbers. Other laboratories are fitted up for studies on adsorption of simple hydrocarbons on carbon black and other powders, as part of the research on the mechanism of filler reinforcement. The second group includes the main chemical research laboratory, at present devoted largely to studies on copper (and other heavy-metal) catalysis of oxidation and the development of improved sequestering agents for combating the effect of copper in promoting oxidative deterioration (ageing) of rubber.

The physics laboratories comprise two large adjacent rooms, one of which is devoted mainly to electrical measurements and has a full range of equipment for studies of volume and surface resist-

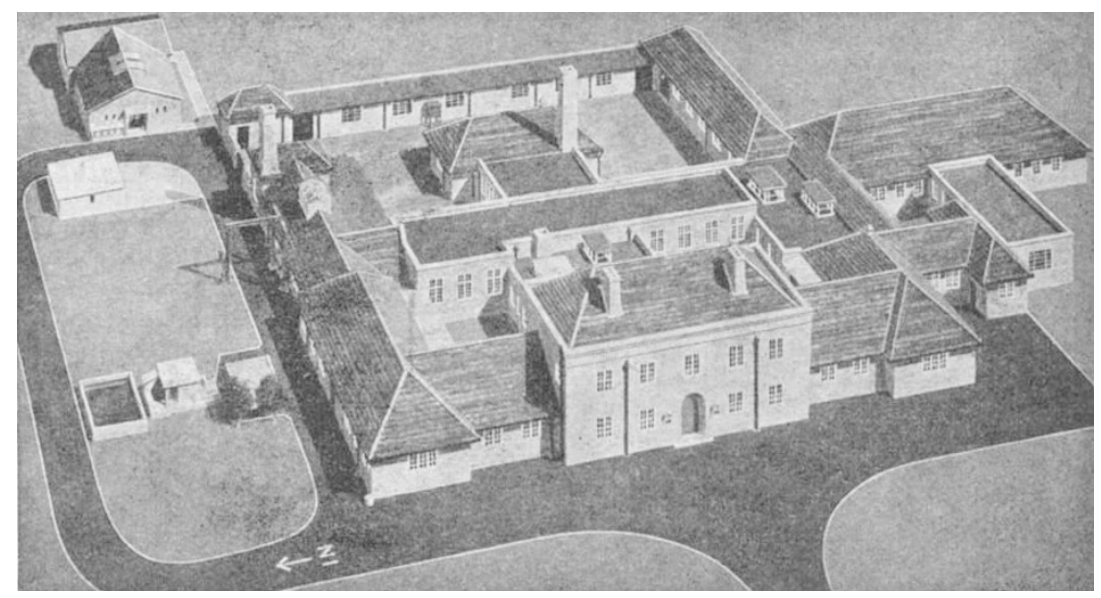

Fig. 1. Aerial view of new Laboratories of the Research Association of British Rubber Manufacturers 